\title{
PERAN KOMITMEN ORGANISASI DALAM MEMEDIASI PENGARUH ORGANIZATIONAL JUSTICE TERHADAP ORGANIZATIONAL CITIZENSHIP BEHAVIOR
}

\author{
(Studi Pada Sopir Taksi Blue Bird Group Jimbaran)
}

\author{
Veby Komalasari Nurwadi ${ }^{1}$ \\ Drs. I Komang Ardana ${ }^{2}$
}

${ }^{1,2}$ Fakultas Ekonomi dan Bisnis Universitas Udayana (Unud), Bali, Indonesia email: vebynurwadi97@gmail.com

\begin{abstract}
ABSTRAK
Penelitian ini bertujuan untuk mengetahui peran komitmen organisasi dalam memediasi pengaruh organizational justice terhadap organizational citizenship behavior pada sopir taksi Blue BirdGroup Jimbaran. Penelitian ini dilakukan di Blue BirdGroup Jimbaran dengan jumlah sopir taksi sebanyak 439 orang. Metode penentuan sampel yang digunakan dalam penelitian ini adalah simple random sampling dengan sampel sebanyak 66 orang. Metode pengumpulan data melalui wawancara dan kuesioner. Teknik analisis data yang digunakan dalam penelitian ini adalah Uji Asumsi Klasik, Path Analysis dan Uji Sobel. Hasil penelitian menunjukkan bahwa organizational justice berpengaruh positif dan signifikan terhadap komitmen organisasi. Komitmen organisasi berpengaruh positif dan signifikan terhadap organizational citizenship behavior. Organizational justice berpengaruh positif dan signifikan terhadap organizational citizenship behavior. Organizational justice berpengaruh positif dan signifikan terhadap organizational citizenship behavior melalui mediasi komitmen organisasi. Pihak perusahaan hendaknya dapat meningkatkan organizational justice dalam perusahaan sehingga dapat meningkatkan komitmen organisasi dan menumbuhkan organizational citizenship behavior dalam diri tiap individu.
\end{abstract}

Kata kunci: komitmen organisasi; organizational justice; organizational citizenship behavior.

\begin{abstract}
This study aims to determine the role of organizational commitment in mediating the effect of organizational justice on organizational citizenship behavior on taxi drivers Blue Bird Group Jimbaran. This research was conducted at Blue Bird Group Jimbaran with a total of 439 taxi drivers. The method of determining the sample used in this study was simple random sampling with a sample of 66 people. Methods of collecting data through interviews and questionnaires. The data analysis technique used in this study is the Classical Assumption Test, Path Analysis and Sobel Test. The results of the study show that organizational justice has a positive and significant effect on organizational commitment. Organizational commitment has a positive and significant effect on organizational citizenship behavior. Organizational justice has a positive and significant effect on organizational citizenship behavior. Organizational justice has a positive and significant effect on organizational citizenship behavior through mediating organizational commitment. The company should be able to improve organizational justice in the company so that it can increase organizational commitment and foster organizational citizenship behavior in each individual.
\end{abstract}

Keywords: organizational commitment; organizational justice; organizational citizenship behavior. 


\section{PENDAHULUAN}

Sumber Daya Manusia (SDM) yang berkompeten dan berkualitas tinggi amat penting bagi keberhasilan suatu organisasi. Hal ini karena keberhasilan suatu organisasi bergantung pada kualitas dan kinerja SDM yang ada pada organisasi tersebut. Faktor utama dari keberhasilan suatu organisasi yang diberikan SDM adalah perilaku ekstra dan keefektifan dalam bekerja. Perilaku ekstra dari SDM sangat dibutuhkan oleh organisasi untuk bisa membantu mendorong kemajuan dari suatu organisasi dan perilaku ekstra ini disebut dengan Organizational Citizenship Behavior. Organizational CitizenshipBehavior (OCB) merupakan perilaku individu yang tumbuhdidasari atas kebijaksanaanseorang karyawan yang dilakukan secara sukarela dan tanpa paksaan (Andriani, 2012). Robbins \& Judge (2015:40) mengemukakan fakta yang menunjukkan bahwa organisasi yang mempunyai karyawan yang memahami Organizational Citizenship Behavior (OCB) yang baik, akan memiliki skill yang lebih baik dari organisasi lain.

Pentingnya membangun OCB pada karyawan tidak lepas dari usaha perusahaan atau organisasi untuk mencari tahu apa yang menyebabkan meningkatnya perilaku OCB. Organ, Podsakoff, \& MacKenzie (2006) menyatakanada beberapa variabel yang dapat mempengaruhi tumbuhnya perilaku OCBkaryawan, diantaranya adalah kepuasan kerja, keadilan,motivasi instrinsik, gayakepemimpinan, budaya dan iklim organisasi, jenis kelamin, masa kerja, persepsiterhadap dukungan organisasi. Dari beberapa faktor yang dapat mempengaruhiOCB, salah satu faktor yaitu, pekerja harus merasa diperlakukan secara adil olehorganisasi (Allamehet al., 2012)

Keadilan organisasimerupakan persepsi keseluruhan dari apa yang adil di tempat kerja (Robbins \& Judge, 2015:249). Menurut Aryee et al. (2002) keadilan organisasi menggambarkan mengenai persepsi individu tentang keadilan yang diterima dari organisasi dan reaksi tingkah lakunya terhadap persepsi tersebut.Keadilanorganisasimerupakan sebuah persepsi karyawan sejauh manamereka diperlakukan adil di dalam organisasi, dan bagaimana persepsitersebut dapat mempengaruhi loyalitas karyawan terhadap organisasi seperti komitmendan kepuasan Najafi et al. (2011). Selain keadilan organisasi yang menjadi fokus dalam penelitian ini adalah komitmen organisasi sebagai mediator dalam menciptakan OCB di dalam perusahaan.

Komitmen organisasi mengacu pada ikatan kekuatan yang mendorong individu ke arah tindakan tertentu untuk mencapai tujuan tertentu (J. . Meyer \& Herscovitch, 2001). Komitmen organisasi merupakan tingkat dimana seorang pekerja mengidentifikasi sebuah organisasi, tujuan dan harapannya untuk tetap menjadi anggota (Robbins \& Judge, 2015:47). Menurut Adiapsari (2012)mengatakan apabila karyawan memiliki komitmen organisasi akan menunjukkan kemauan bekerja keras untuk mencapai tujuan organisasi dan memiliki keinginan kuat untuk bekerja dan tetap bertahan di lembaga tempatnya bekerja.

Menurut Wibowo (2012:300)komitmen organisasi tidak dapat terbentukdengan cepat akan tetapi perlu dibangun dengan bertahap, komitmen organisasi diawali dengan membangun hubungan baik antar individu, sehingga timbul kepedulian. Komitmen organisasi dapat ditumbuhkan dalam diri tiap 
individu melalui lingkungan kerja. Perusahaan yang selalu memberikan sikap peduli dan adil kepada karyawan, dapat menumbuhkan komitmen organisasi yang tinggi. Karyawan yang berkomitmen dapat menurunkan tingkat keinginan pengunduran diri, walaupun merasa tidak puas, karena telah memiliki rasa kesetian yang besar terhadap organisasi, hal itu tidak menjadi masalah bagi karyawan dan tidak memutuskan untuk keluar dari perusahaan.

Penelitian ini dilandasi oleh research gapdari penelitian-penelitian terdahulu. Penelitan oleh Khan \& Rashid (2012)mengatakan bahwa komitmen organisasi dapat menjadi variabel mediasi yang sesuai untuk mengetahui hubungan antara budaya organisasi, gaya kepemimpinan, dan keadilan organisasi terhadap OCB, karena dalam penelitian ini komitmen organisasi memiliki pengaruh positif dan signifikan terbesar bila dibandingkan dengan variabelvariabel lainnya. Berbeda dari hasil penelitian yang dilakukan oleh Moorman, et al. (1993) yang mengatakan bahwa komitmen organisasional dan kepuasan kerja tidak terbukti sebagai variabel mediasi antara hubungan keadilan organisasi terhadap OCB karena hasil pada penelitian ini menyatakan bahwa hubungan antara keadilan organisasi terhadap OCB secara langsung lebih besar.

Penelitian yang dilakukan oleh Karim \& Reham (2012), Dehkordi \& Yektayar (2013), Oceani \& Sriathi (2015), Praditya \& Putra (2016)menghasilkankesimpulan yaitu keadilan organisasi berpengaruh positif dan signifikan terhadap komitmen organisasi, rendahnya keadilan dalam organisasi akan menciptakan komitmen organisasi yang rendah. Berbeda dengan hasil penelitian Ibrahim \& Perez (2014) bahwa persepsi dari tiga komponen keadilan (distributif, prosedural dan interaksional) tidak memiliki pengaruh langsung terhadap komitmen karyawan. Penelitian lain yang dilakukan Rini dkk. (2013)menunjukkan bahwa komitmen organisasi memiliki pengaruh positif dan signifikkan terhadap OCB. Berbeda dengan hasil penelitian tersebut, penelitian Darmawati dkk. (2013)yang menyatakan komitmen organisasi ternyata tidak memiliki pengaruh terhadap variabel OCB.

Penelitian oleh Ibrahim \& Perez (2014)menghasilkan bahwa keadilan organisasi berpengaruh postitif terhadap OCB. Penelitian Nwibere (2014)menghasilkan kesimpulanorganizatioal justice memiliki pengaruh positif dan signifikan terhadap OCB. Bertolak belakang dengan penelitian Khan \& Rashid (2012) yang menghasilkan kesimpulan keadilan organisasi tidak berpengaruh terhadap OCB.

Blue Bird Group merupakan perusahaan transportasi yang berasal dari Indonesia, Blue Bird Group telah melebarkan bisnisnya di beberapa wilayah di Indonesia. Penelitian ini dilaksanakan di Blue Bird Group Jimbaran yang terletak di Jalan By Pass Nusa Dua No. 4, Jimbaran, Bali dengan sampel yakni sopir taksi. Berdasarkan hasil wawancara yang dilakukan dengan HRD Blue Bird Group Jimbaran ditemukan permasalahan mengenai OCB pada para sopir taksi.

Data dalam Grafik 1 menunjukkan tentang keluhan konsumen yang ada hubungannya dengan perusahaan mengenai perilaku OCB dari parasopir taksi Blue Bird Group Jimbaran. Berikut merupakan data keluhan konsumen Blue Bird Group Jimbaran. 


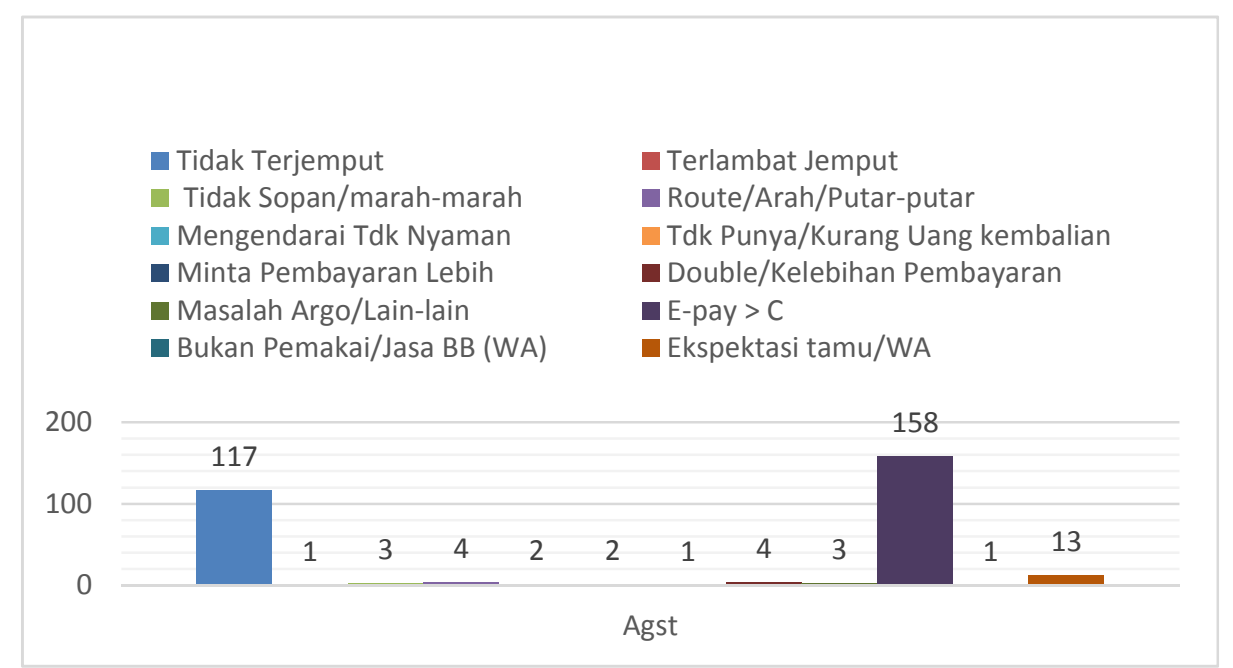

Grafik 1. Data Keluhan Konsumen Blue Bird Group Jimbaran

Sumber : Blue Bird Group Jimbaran, 2018

Data dari Grafik 1. menunjukkan ada beberapa di kalangan para sopir yang mengindikasikan masih kurangnya perilaku OCB para sopir taksi Blue Bird Group Jimbaran. Terlihat pada Grafik 1 keluhan konsumen tidak terjemput dan $E$ pay yang paling banyak terjadi. Hasil dari keluhan konsumen Blue Bird Group Jimbaran yaitu konsumen tidak terjemput sebanyak 117 keluhan dan E-pay sebanyak 158 keluhan. Berdasarkan data tersebut, dapat diketahui bahwa perilaku OCB para sopir taksi Blue Bird Group Jimbaran masih rendah.

Rumusan masalah dalam penelitian ini (1) Bagaimanakan organizational justice berpengaruh terhadap organizational citizenship behavior pada sopir taksi Blue Bird Group Jimbaran? (2) Bagaimanakah organizational justice berpengaruh terhadap komitmen organisasi pada sopir taksi Blue Bird Group Jimbaran? (3) Bagaimanakah komitmen organisasi berpengaruh terhadap organizational citizenship behavior sopir taksi Blue Bird Group Jimbaran? (4) Bagaimanakah komitmen organisasi memediasi pengaruh organizational justice terhadap organizational citizenship behavior sopir taksi Blue Bird Group Jimbaran?

Manfaat penelitian ini yaitu diharapkan mampu memberikan bukti empiris dalam bidang ilmu manajemen sumber daya manusia, khususnya mengenai organizational justice, organizational citizenship behavior dan komitmen organisasi serta menjadi referensi bagi perusahaan sebagai bahan pertimbangan dan masukan mengenai sejauh mana peran komitmen organisasi dalam memediasi organizational justice terhadap organizational citizenship behavior. Diharapkan penelitian ini dapat menyumbangkan pemikiran dan menjadi acuan dalam menentukan kebijakan strategi pengelolaan sumber daya manusia di masa depan.

Teori yang melandasi penelitian ini adalah teori pertukaran sosial. Teori ini pertama kali dikemukakan oleh George C. Homans dan dikembangkan oleh Peter Blau. Awalnya teori ini hanya menitik beratkan pada hubungan antar individu, kemudian dikembangkan oleh Blau menjadi lebih luas yaitu antara individu dengan kelompok. Teori ini didasarkan pada hubungan yang semakin erat sampai pada saling percaya, loyal, dan saling berkomitmen antara kedua belah pihak (Cropanzano \& Mitchell, 2005) 
Funget al.(2015) menyatakan bahwa teori pertukaran sosial merupakan pandangan karyawan ketika mereka telah diperlakukan dengan baik oleh organisasi, mereka akan cenderung untuk melakukan balas budi terhadap organisasi dengan bersikap dan berperilaku lebih positif. Konovsky \&Pugh(1994)dalam Soegandhi dkk.(2013)menggunakan teori pertukaran sosial untuk berpendapat bahwa ketika karyawan telah puas terhadap pekerjaannya, mereka akan membalasnya, pembalasan dari karyawan tersebut termasuk perasaan memiliki yang kuat terhadap organisasi dan perilaku seperti OCB.

Organizational Citizenship Behavior (OCB) adalahperilaku yang bebas dan tidak secara langsung dapat diakui oleh sistem pemberian penghargaan dan dalam mempromosikan fungsi efektif organisasi (Soegandhi dkk. 2013). Robbins (2006)mengemukakan bahwa OCB merupakan perilaku pilihanyang tidak menjadi bagian dari kewajiban kerja formal seorang karyawan namunmendukung berfungsinya organisasi tersebut secara efektif. OCB merupakan perilaku sukarela dari seorang pekerja untuk mau melakukan tugas atau pekerjaan di luar tanggung jawab atau kewajibannya demi kemajuan atau keuntungan organisasinya (Waspodo \& Minadaniati, 2012)

Menurut Organ et al. (2006)terdapat lima indikator OCB yaitu: (1) Altruism, yaitu perilaku sukarela dimana seorang karyawan memberikan bantuan kepada individu dengan masalah tertentu untuk membantu tugas orang lain di luar tugas wajibnya.(2) Conscientiousness, yaitu perilaku karyawan yang ditunjukkan melalui penggunaan waktu yang efisien dan tingkat kehadiran yang tinggi serta mematuhi peraturan organisasi. (3) Sportsmanship, yaitu perilaku yang mentoleransi bagian yang tidak dapat dihindari di setiap pengaturan organisasi dan dengan adanya sportifitas dapat meningkatkan moral kelompok kerja sehingga mampu menekan tingkat konflik. (4) Courtesy,yaitu perilaku yang mencegah masalah dan mengambil langkah-langkah penting untuk mengurangi hasil dari masalah di masa depan. (5) Civic Virtue, yaitu perilaku untuk meningkatkan kualitas kinerja dan membantu dalam mengurangi keluhan pelanggan.

Komitmen organisasi didefinisikan sebagai kekuatan yang mengikat individu pada target (sosial atau non-sosial) dan ke arah tindakan yang berhubungan dengan target (Meyer et al., 2006).Komitmen organisasi adalah fungsi dari kepuasan kerja, menurut Adeyemo (2007)ia mengklaim bahwa ketika kebutuhan karyawan terpenuhi ada kemungkinan tingkat komitmen pekerja akan tinggi.Komitmen organisasi merupakan pengikat antara karyawan dengan organisasi. Karyawan yang berkomitmen tinggi terhadap organisasi, akan selalu memberikan yang terbaik meliputi, loyalitas, tekad kuat dalam bekerja demi kesuksessan organisasi, dan terus mendedikasikan diri kepada organisasi.

Menurut Noordin et al.(2010)menyatakan ada tiga indikator komitmen organisasi, yaitu: (1) Komitmen afektif (affective commitment) mengacu pada perasaan emosional dan keterlibatan karyawan dengan organisasinya mencakup kesetiaan dan rasa memiliki terhadap organisasi. (2) Komitmen berkelanjutan (continuence commitment) mengacu pada apa yang akan karyawan korbankan jika mereka harus meninggalkan organisasi. (3) Komitmen normatif (normative 
commitment) menggambarkan perasaan dari kewajiban karyawan dalam pekerjaannya.

Definisi keadilan organisasi menurut Ozkalp \& Kirel (2004)yaitu mencakup semua pertukaran sosioekonomi bersama dalam organisasi seperti tugas, pembayaran, penghargaan, hukuman dan promosi, serta hubungan karyawan dengan atasan, rekan kerja, dan organisasi itu sendiri sebagai sistem sosial. Menurut Marissa (2010) keadilan organisasi merupakan suatu tindakan ataupun perlakuan, yang diterima oleh tiap karyawan sama tanpa membedakan status jabatan ataupun kedudukan masing-masing individu dan dapat dikatakan adil apabila karyawan mendapatkan hak-hak sesuai dengan apa yang karyawan berikan kepada perusahaan. Keadilan organisasi adalah suatu konsep teoritis mengenai bagaimana orang-orang diperlakukan dalam suatu organisasi dan biasanya dibagi menjadi dua dimensi: keadilan distributif dan prosedural (Muchinsky, 2008)

Menurut Colquitt (2001)menyebutkan terdapat tiga indikator organizational justice, yaitu: (1) Keadilan distributif menjelaskan mengenai alokasi hasil-hasil yang konsisten, yang berhubungan dengan teori keadilan organisasi yang menjelaskan bahwa seseorang akan mendapatkan hasil-hasil (outcomes) dan penghargaan (reward) yang sesuai. (2) Keadilan prosedural mencerminkan para karyawan tidak hanya memberikan reaksi terhadap hasil-hasil (outcomes) yang mereka dapatkan, tetapi juga terhadap proses-proses bagaimana mereka mendapatkan hasil tersebut. (3) Keadilan interaksional merupakan nilai keadilan yang dirasakan karyawan karna adanya proses interaksi antar individu dalam organisasi baik dari pimpinan maupun rekan kerja.

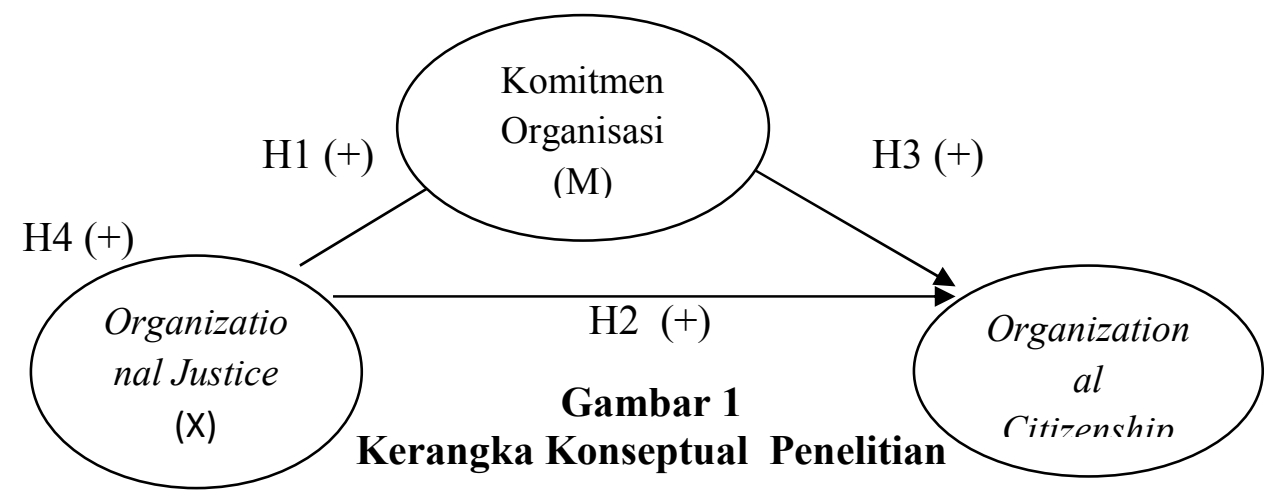

Penelitian yang dilakukan oleh Tahseen \& Akhtar (2016),Sanhaji, Soetjipto, \& Suharto (2016), Polat (2016), Ibrahim \& Perez (2014), Nwibere (2014)menyatakan organizational justice berpengaruh positif dan signifikan terhadap organizational citizenship behavior.

$\mathrm{H}_{1}$ : Organizational justice berpengaruh positif dan signifikan terhadap organizational citizenship behavior.

Penelitian yang dilakukan oleh Sutrisna \& Rahyuda (2014), Mensah, Asiamah, \& Mireku (2016),Kristanto (2015), Lashari et al. (2016), Sancoko \& Panggabean (2015) menyatakan organizational justice berpengaruh positif dan signifikan terhadap komitmen organisasi. 
$\mathrm{H}_{2}$ : Organizational justice berpengaruh positif dan signifikan terhadap komitme organisasi.

Menurut penelitian yang dilakukan oleh Ortiz, Rosario, Marquez, \& Gruneiro (2015), Fitria dkk.(2015), Kurniawan (2015) , Barusman \& Mihdar (2014), Kencanawati (2014)menyatakan komitmen organisasi berpengaruh positif dan signifikan terhadap organizational citizenship behavior.

$\mathrm{H}_{3}$ : Komitmen organisasi berpengaruh positif dan signifikan terhadap organizational citizenship behavior.

Penelitian yang dilakukan oleh Nandan \& Abdul (2015), Awang \& Wan (2015), Suwandewi \& Sintaasih (2016), Indrayani \& Suwandana (2016), Prameswari (2017), Bara, Patricia, \& Andi (2016), Khan \& Rashid (2012)menyatakan komitmen organisasi memediasi pengaruh organizational justice terhadap organizational citizenship behavior.

$\mathrm{H}_{4}$ : Komitmen organisasi memediasi pengaruh organizational justice terhadap organizational citizenship behavior.

\section{METODE PENELITIAN}

Penelitian ini dilakukan dengan menggunakan metode asosiatif. Penggunaan metode ini dengan tujuan untuk mengetahui peran komitmen organisasi dalam memediasi pengaruh organizational justice terhadap organizational citizenship behavior. Penelitian ini dilakukan di Jalan By Pass Nusa Dua No 4, Jimbaran. Blue Bird Group Jimbaran dipilih sebagai tempat penelitian karena belum adanya dilakukan penelitian dengan variabel organizational justice, komitmen organisasi dan organizational citizenship behavior di perusahaan tersebut serta ditemukan permasalahan yang berkaitan dengan OCB para sopir taksi dalam perusahaan setelah dilakukan wawancara dengan Human Resource Departement Blue Bird Group Jimbaran terlebih dahulu. Obyek dalam penelitian ini adalah organizational justice $(\mathrm{X})$, organizational citizenship behavior $(\mathrm{Y})$ dan komitmen organisasi (M) pada sopir taksi Blue Bird Group Jimbaran.

Jenis data yang digunakan dalam penelitian ini ada dua, yaitu data kuantitatif berupa jumlah sopir taksi dan data yang langsung didapat dari sopir taksi Blue Bird Group Jimbaran dengan cara penyebaran kuesioner. Data kualitatif berupa skema yang terkait dengan variabel-variabel yang diteliti, data yang didapatkan dari riset awal melalui wawancara non-formal dengan Human Resource Departement Blue Bird Group Jimbaran serta tanggapan yang diberikan oleh responden dalam kuesioner.

Uji validitas dilakukan untuk mengetahui apakah kuisioner sudah sesui untuk dapat mengukur indikator dalam penelitian. Kuisioner dapat dinyatakan valid apabila pertanyaan ataupun pernyataan dalam kuisioner dapat menggambarkan sesuatu yang akan diukur oleh kuisioner itu. Pertanyaan ataupun pernyataan yang dikatakan valid dalam kuisioner apabila koefisien korelasi $\geq 0,3$ (Sugiyono, 2017). Pengujian reliabilitas instrumen merupakan syarat pengujian validitas instrumen yang harus dilakukan karena instrumen yang validsecara keseluruhan reliable, namun proses uji reliabilitas instrument tetap dilakukan untuk mengetahui sejauh mana kemantapan alat ukur yang akan digunakan, sehingga apabila alat ukur tersebut digunakan kembali untuk meneliti suatu objek 
yang sama walaupun waktunya berbeda, maka hasil yang diperoleh akan sama (Sugiyono, 2017).

Populasi dalam penelitian ini adalah sopir taksi Blue Bird Group Jimbaran yang berjumlah 439 orang. Metode penentuan sampel yang digunakan dalam penelitian ini adalah simple random sampling karena pengambilan anggota sampel dari populasi dilakukan secara acak tanpa memperhatikan strata yang ada dalam populasi itu. Jadi, sampel yang digunakan dalam penelitian ini adalah 66 sopir taksi.

Metode pengumpulan data yang digunakan ada dua, yaitu wawancara yang dilakukan oleh peneliti kepada para sopir taksi dan Human Resource Departement Blue Bird Group Jimbaran secara mendalam mengenai variabel dalam penelitian ini. Kuesioner dapat berupa pertanyaan/pernyataan tertutup atau terbuka dapat diberikan kepada responden secara langsung atau dikirim melalui pos atau internet (Sugiyono, 2017:225).

Teknik analisis data yang digunakan dalam penelitian ini berupa analisis statistik deskriptif, uji asumsi klasik yang terdiri dari uji normalitas, uji multikoliniaritas dan uji heteroskedastisitas, analisis statistik inferensial, analisis jalur. Setelah melakukan uji analisis jalur maka dilakukan uji koefisien determinasi, uji f dan uji t dan uji sobel.

\section{HASIL DAN PEMBAHASAN}

Penelitian ini dilakukan dengan menyebarkan kuesioner sebanyak 66 kuesioner kepada responden, maka proporsi karakteristik responden yang diperolah sebagai berikut.

Tabel 1. menunjukkan seluruh pernyataan pada variabel organizational justcie, komitmen organisasi dan organizational citizenship behavior memiliki nilai koefisien korelasi dengan skor lebih besar dari 0,30. Hasil uji validitas memperoleh nilai koefiesien korelasi terkecil sebesar 0,640 dan nilai koefisiesn korelasi terbesar sebesar 0,870 . Uji validitas menandakan seluruh indikator tersebut telah memenuhi syarat validitas data dan dapat dinyatakan valid.

Tabel 2. menunjukkan tiga karakteristik dari responden yang terdiri dari usia, pendidikan terakhir dan masa kerja. Berdasarkan klasifikasi usia, responden pada penelitian ini sebagian besar berusia 46 hingga 50 tahun dengan persentase sebesar 48,49 persen yang berjumlah 32 orang. Berdasarkan klasifikasi tingkat pendidikan responden sebagaian besar merupakan lulusan SMA dengan jumlah 54 orang atau 81,82 persen. Berdasarkan klasifikasi masa kerja responden diketahui sebagian besar memiliki masa kerja lebih dari 20 tahun, yaitu sebanyak 25 orang atau 37,88 persen.

Tabel 3. menunjukkan ketiga instrument penelitian yaitu variabel organizational justice, komitmen organisasi dan organizational citizenship behavior memiliki nilai Cronbach's Alpha lebih besar dari 0,6 sehingga dapat disimpulkan bahwa seluruh variabel memiliki syarat reliabilitas instrumen dan dapat dinyatakan reliabel. 
Tabel 1.

Hasil Uji Validitas

\begin{tabular}{ccccc}
\hline No & Variabel & $\begin{array}{c}\text { Item } \\
\text { Pernyataa } \\
\text { n }\end{array}$ & $\begin{array}{c}\text { Korelas } \\
\text { i Item } \\
\text { Total }\end{array}$ & Keterangan \\
\hline \multirow{3}{*}{1} & Organizational & $\mathrm{X}_{1}$ & 0,696 & Valid \\
& justice (X) & $\mathrm{X}_{2}$ & 0,824 & Valid \\
& & $\mathrm{X}_{3}$ & 0,870 & Valid \\
& Komitmen & $\mathrm{M}_{1}$ & 0,819 & Valid \\
& & $\mathrm{M}_{2}$ & 0,786 & Valid \\
& organisasi (M) & $\mathrm{M}_{3}$ & 0,859 & Valid \\
& Organizational & $\mathrm{Y}_{1}$ & 0,737 & Valid \\
& citizenship behavior & $\mathrm{Y}_{2}$ & 0,757 & Valid \\
& (Y) & $\mathrm{Y}_{3}$ & 0,640 & Valid \\
& & $\mathrm{Y}_{4}$ & 0,831 & Valid \\
& & $\mathrm{Y}_{5}$ & 0,676 & Valid \\
\hline
\end{tabular}

Sumber : Data diolah (2018)

Tabel 2.

Karakteristik Responden

\begin{tabular}{|c|c|c|c|}
\hline \multirow[t]{2}{*}{ No } & \multirow[t]{2}{*}{ Tingkat Usia (Tahun) } & \multicolumn{2}{|c|}{ Jumlah } \\
\hline & & Orang & $\begin{array}{l}\text { Persen } \\
(\%)\end{array}$ \\
\hline 1 & $40-45$ & 6 & 9,09 \\
\hline 2 & $46-50$ & 32 & 48,49 \\
\hline 3 & $51-55$ & 22 & 33,33 \\
\hline \multirow[t]{2}{*}{4} & $56-60$ & 6 & 9,09 \\
\hline & Jumlah & 66 & 100 \\
\hline No & \multicolumn{3}{|c|}{ Tingkat Pendidikan } \\
\hline 1 & SMP & 12 & 18,18 \\
\hline \multirow[t]{2}{*}{2} & SMA & 54 & 81,82 \\
\hline & Jumlah & 66 & 100 \\
\hline No & \multicolumn{3}{|c|}{ Masa Kerja (Tahun) } \\
\hline 1 & $10-15$ & 6 & 9,09 \\
\hline 2 & $16-20$ & 35 & 53,03 \\
\hline 3 & $21-25$ & 25 & 37,88 \\
\hline & Jumlah & 66 & 100 \\
\hline
\end{tabular}

Sumber : Data primer diolah (2018) 
Tabel 3.

Hasil Uji Reliabilitas

\begin{tabular}{cccc}
\hline No & Variabel & $\begin{array}{c}\text { Cronbach's } \\
\text { Alpha }\end{array}$ & Keterangan \\
\hline 1 & Organizational justice (X) & 0,718 & Reliabel \\
& Komitmen organisasi (M) & 0,759 & Reliabel \\
2 & $\begin{array}{c}\text { Organizational citizenship } \\
\text { behavior }(\mathrm{Y})\end{array}$ & 0,781 & Reliabel \\
3 & Sumber: Data diolah (2018) & &
\end{tabular}

Tabel 4.

Deskripsi Jawaban Responden mengenai Variabel

Organizational Justice

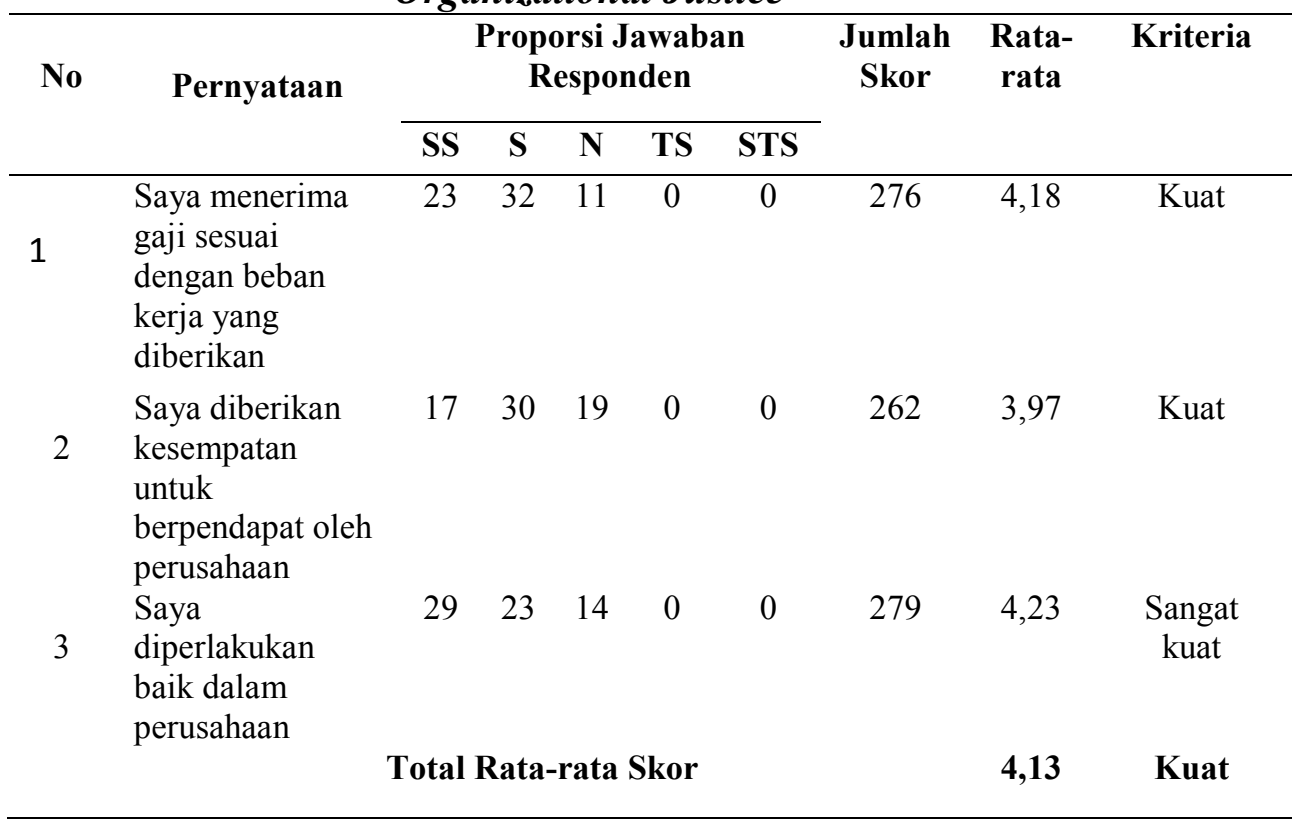

Sumber: Data diolah (2018)

Tabel 4. menunjukkan tiga pernyataan mengenai organizational justice memperoleh rata-rata sebesar 4,13 yang berarti keadilan organisasi yang dirasakan oleh para sopir taksi berada pada kriteria kuat.

Tabel 5. menunjukkan tiga pernyataan mengenai komitmen organisasi memperoleh nilai rata-rata sebesar 4,15 yang berarti komitmen organisasi para sopir taksi terhadap perusahaan berada pada kriteria kuat.

Tabel 6. menunjukkan lima pernyataan mengenai organizational citizenship behavior memperoleh nilai rata-rata sebesar 4,15 yang berarti perilakuOCB pada para sopir taksi berada berada pada kriteria kuat.

Tabel 7. menunjukkan nilai Kolmogorov-Smirnov sebesar 0,618, dan nilai Asymp.Sig. (2-tailed) sebesar 0,839. Hasil tersebut menandakan bahwa model 
persamaan regresi tersebut berdistribusi normal karena nilai Asymp.Sig. (2-tailed) 0,839 lebih besar dari nilai alpha 0,05 .

Tabel 5.

Deskripsi Jawaban Responden mengenai Variabel Komitmen Organisasi

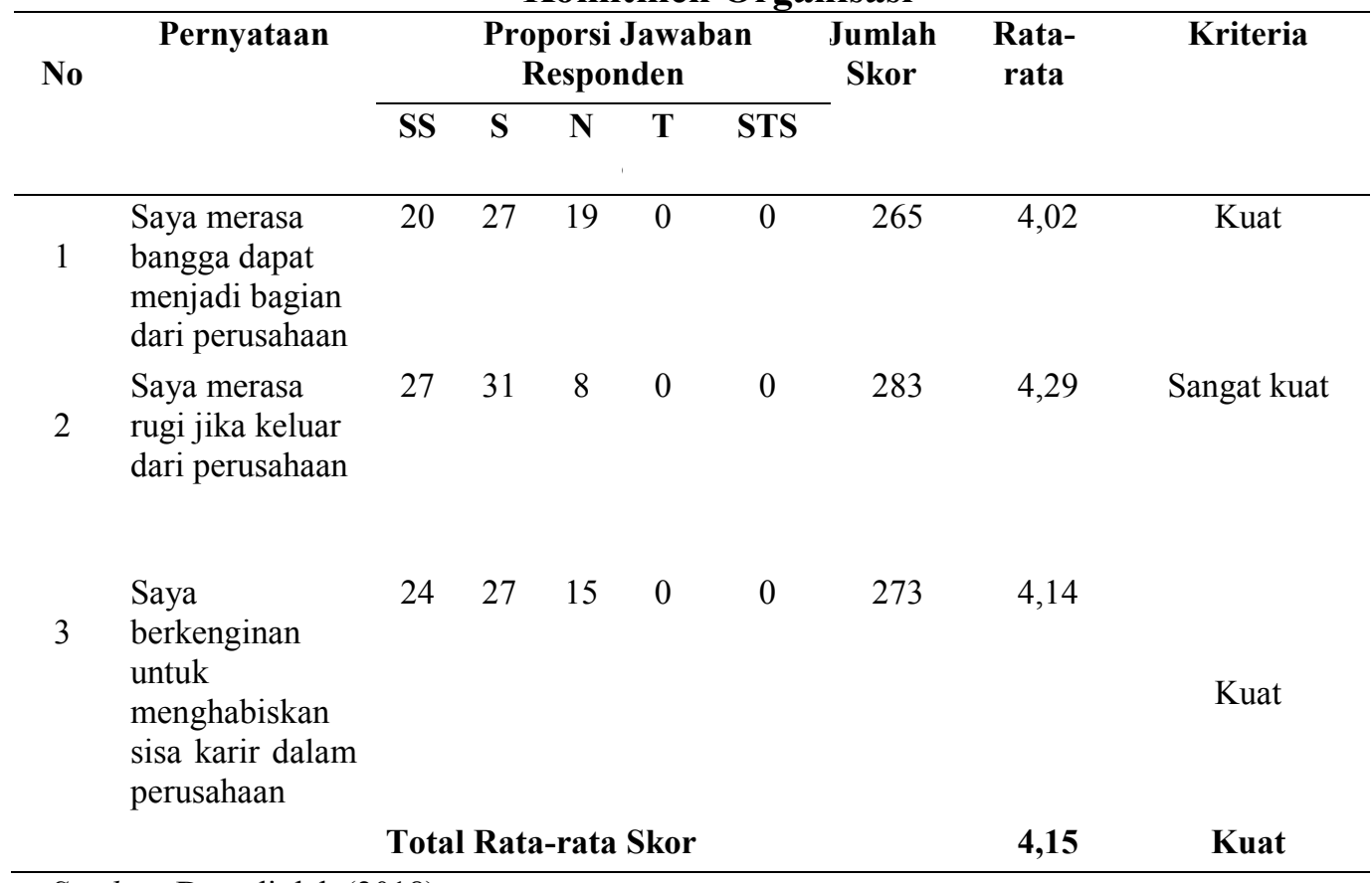

Sumber: Data diolah (2018)

Tabel 6.

Deskripsi Jawaban Responden mengenai Variabel Organizational Citizenship Behavior

\begin{tabular}{|c|c|c|c|c|c|c|c|c|c|}
\hline \multirow[t]{2}{*}{ No } & \multirow[t]{2}{*}{ Pernyataan } & \multicolumn{5}{|c|}{$\begin{array}{l}\text { Proporsi Jawaban } \\
\text { Responden }\end{array}$} & \multirow[t]{2}{*}{$\begin{array}{l}\text { Jumlah } \\
\text { Skor }\end{array}$} & \multirow[t]{2}{*}{ Rata-rata } & \multirow[t]{2}{*}{ Kriteria } \\
\hline & & SS & $\mathbf{S}$ & $\mathbf{N}$ & TS & STS & & & \\
\hline 1 & $\begin{array}{l}\text { Saya bersedia dalam } \\
\text { membantu rekan } \\
\text { kerja ketika } \\
\text { mengalami kesulitan }\end{array}$ & 26 & 28 & 12 & 0 & 0 & 278 & 4,21 & Sangat kuat \\
\hline 2 & $\begin{array}{l}\text { Saya bersedia } \\
\text { menghindari } \\
\text { perselisihan antar } \\
\text { rekan kerja dalam } \\
\text { perusahaan. }\end{array}$ & 22 & 28 & 16 & 0 & 0 & 270 & 4,09 & Kuat \\
\hline
\end{tabular}

Bersambung... 


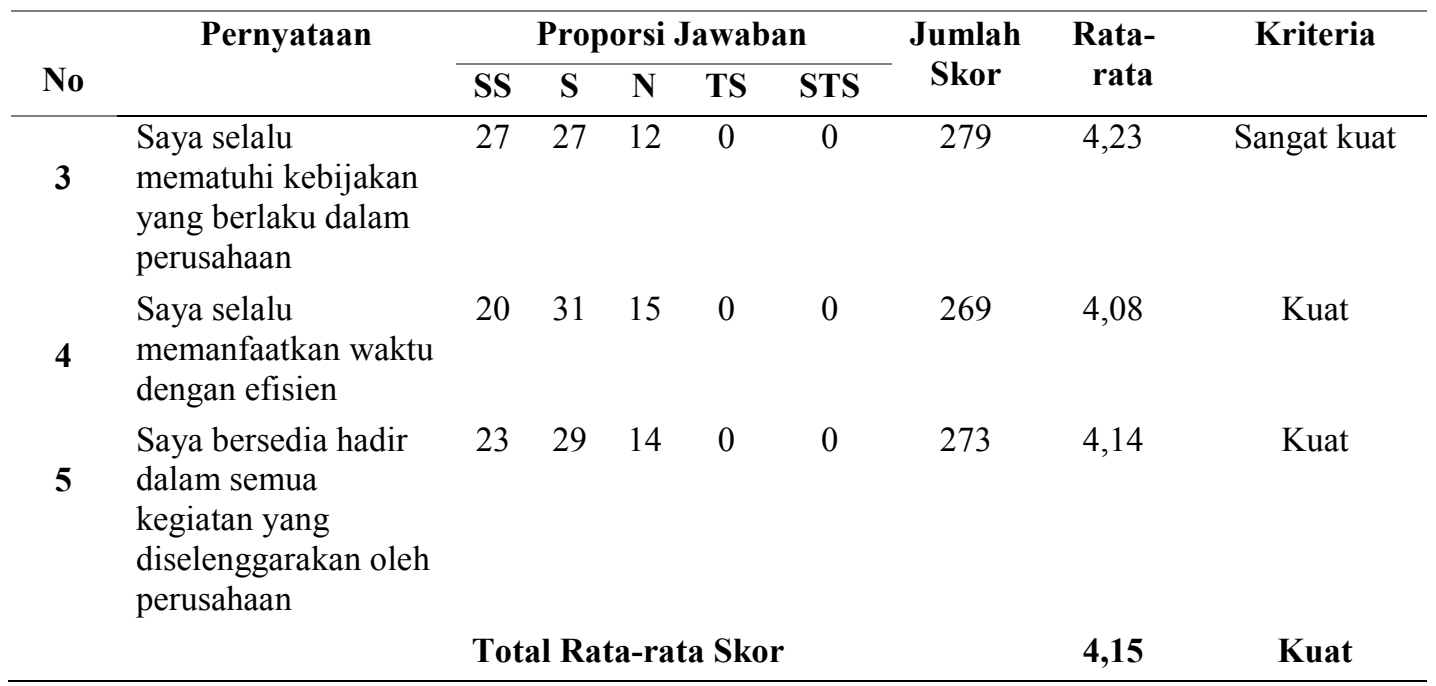

Sumber: Data diolah (2018)

Tabel 7.

Hasil Uji Normalitas Persamaan Regresi 1

\begin{tabular}{cc}
\hline & Unstandardized Residual \\
\hline $\mathrm{N}$ & 66 \\
Kolmogorov-Smirnov $Z$ & 0,618 \\
Asymp.Sig. (2-tailed) & 0,839 \\
\hline
\end{tabular}

Sumber: Data diolah (2018)

Tabel 8.

Hasil Uji Normalitas Persamaan Regresi 2

\begin{tabular}{cc}
\hline & Unstandardized Residual \\
\hline $\mathrm{N}$ & 66 \\
Kolmogorov-Smirnov $Z$ & 0,817 \\
Asymp.Sig. (2-tailed) & 0,517 \\
\hline
\end{tabular}

Sumber: Data diolah (2018)

Tabel 8. menunjukkan nilai Kolmogorov-Smirnov sebesar 0,817, dan nilai Asymp.Sig. (2-tailed) sebesar 0,517. Hasil tersebut menandakan bahwa model persamaan regresi tersebut berdistribusi normal karena nilai Asymp.Sig. (2-tailed) 0,517 lebih besar dari nilai alpha 0,05 . 
Tabel 9.

Hasil Uji Multikoleniaritas Persamaan Regresi 1

\begin{tabular}{ccc}
\hline Variabel & Tolerance & VIF \\
\hline $\begin{array}{c}\text { Organizational justice } \\
(X)\end{array}$ & 1.000 & 1.000 \\
\hline
\end{tabular}

Sumber: Data diolah (2018)

Tabel 9. menunjukkan nilai tolerance dan VIF dari variabel organizational justice. Nilai tersebut memperlihatkan bahwa nilai tolerance sebesar $1.000>0,10$ dan nilai VIF $1.000<10$. Hasil ini menandakan bahwa tidak terdapat gejala multikoleniaritas dari model regresi.

Tabel 10.

Hasil Uji Multikoleniaritas Persamaan Regresi 2

\begin{tabular}{ccc}
\hline Variabel & Tolerance & VIF \\
\hline Organizational justice $(\mathrm{X})$ & 0,541 & 1.848 \\
Komitmen organisasi $(\mathrm{M})$ & 0,541 & 1.848 \\
\hline
\end{tabular}

Sumber: Data diolah (2018)

Tabel 10. menunjukkan nilai tolerance dan VIF dari variabel organizational justice dan komitmen organisasi. Nilai tersebut memperlihatkan bahwa nilai tolerance sebesar 0,541 lebih besar dari 0,10 dan nilai VIF sebesar 1.848 kurang dari 10. Hasil ini menandakan bahwa tidak terdapat gejala multikoleniaritas dari model regresi.

Tabel 11.

\begin{tabular}{ccccccc}
\multicolumn{6}{c}{ Hasil Uji Heteroskedastisitas Persamaan Regresi 1 } \\
\hline \multirow{2}{*}{ Model } & $\begin{array}{c}\text { Unstandardized } \\
\text { Coefficients }\end{array}$ & $\begin{array}{c}\text { Standardized } \\
\text { Coefficients }\end{array}$ & & \\
& & $\mathbf{B}$ & Std.Error & Beta & & Sig. \\
\cline { 2 - 5 } & & 0,270 & 0,218 & & 1.240 & 0,219 \\
\hline 1 & (Constant) & & & & & \\
Org. Justice & 0,015 & 0,052 & 0,035 & 0,283 & 0,778 \\
\hline
\end{tabular}

Sumber : Data diolah, (2018)

Tabel 11. menunjukkan nilai Sig. dari variabel organizational justice sebesar 0,778 lebih besar dari 0,05 yang berarti model yang dibuat tidak mengandung gejala heteroskedastisitas.

Tabel 12. menunjukkan nilai Sig. dari variabel organizational justice dan komitmen organisasi masing-masing sebesar 0,434 dan 0,609. Nilai tersebut lebih besar dari 0,05 yang berarti model yang dibuat tidak mengandung gejala heteroskedastisitas. 
Tabel 12.

Hasil Uji Heteroskedastisitas Persamaan Regresi 2

\begin{tabular}{|c|c|c|c|c|c|}
\hline \multirow[t]{2}{*}{ Model } & \multicolumn{2}{|c|}{$\begin{array}{c}\text { Unstandardized } \\
\text { Coefficients }\end{array}$} & \multirow{2}{*}{$\begin{array}{c}\begin{array}{c}\text { Standardize } \\
d \\
\text { Coefficients }\end{array} \\
\text { Beta }\end{array}$} & \multirow{2}{*}{$\mathbf{t}$} & \multirow{2}{*}{ Sig. } \\
\hline & B & Std. Error & & & \\
\hline $1 \quad$ (Constant) & 0,522 & 0,191 & & 2.730 & 0,008 \\
\hline Org. Justice & $-0,045$ & 0,057 & -0.132 & $-0,788$ & 0,434 \\
\hline Komitmen org & $-0,030$ & 0,057 & -0.086 & $-0,514$ & 0,609 \\
\hline
\end{tabular}

Hasil analisis jalur sub-struktur 1 seperti pada Tabel 13, maka persamaan strukturalnya adalah sebagai berikut:

$$
\begin{aligned}
& \mathrm{Y}_{1}=\beta_{1} \mathrm{X}+\mathrm{e}_{1} \ldots \ldots \\
& \mathrm{Y}_{1}=0,677 \mathrm{X}+\mathrm{e}_{1}
\end{aligned}
$$

Tabel 13.

\begin{tabular}{|c|c|c|c|c|c|}
\hline \multirow[t]{2}{*}{ Model } & \multicolumn{2}{|c|}{$\begin{array}{c}\text { Unstandardized } \\
\text { Coefficients }\end{array}$} & \multirow{2}{*}{$\begin{array}{c}\begin{array}{c}\text { Standardized } \\
\text { Coefficients }\end{array} \\
\text { Beta }\end{array}$} & \multirow[t]{2}{*}{$\mathbf{t}$} & \multirow[t]{2}{*}{ Sig. } \\
\hline & $\mathbf{B}$ & $\begin{array}{c}\text { Std. } \\
\text { Error }\end{array}$ & & & \\
\hline (Constant) & 1.375 & 0,380 & & 3.622 & 0.001 \\
\hline Org. Justice & 0,672 & 0,091 & 0,677 & 7.366 & 0.000 \\
\hline $\mathrm{R}^{2} \quad: 0,459$ & & & & & \\
\hline F Hitung : :54.261 & & & & & \\
\hline Sig F $\quad: 0.000$ & & & & & \\
\hline
\end{tabular}

Hasil Analisis Jalur Persamaan Regresi 1

Tabel 14.

Hasil Analisis Jalur Persamaan Regresi 2

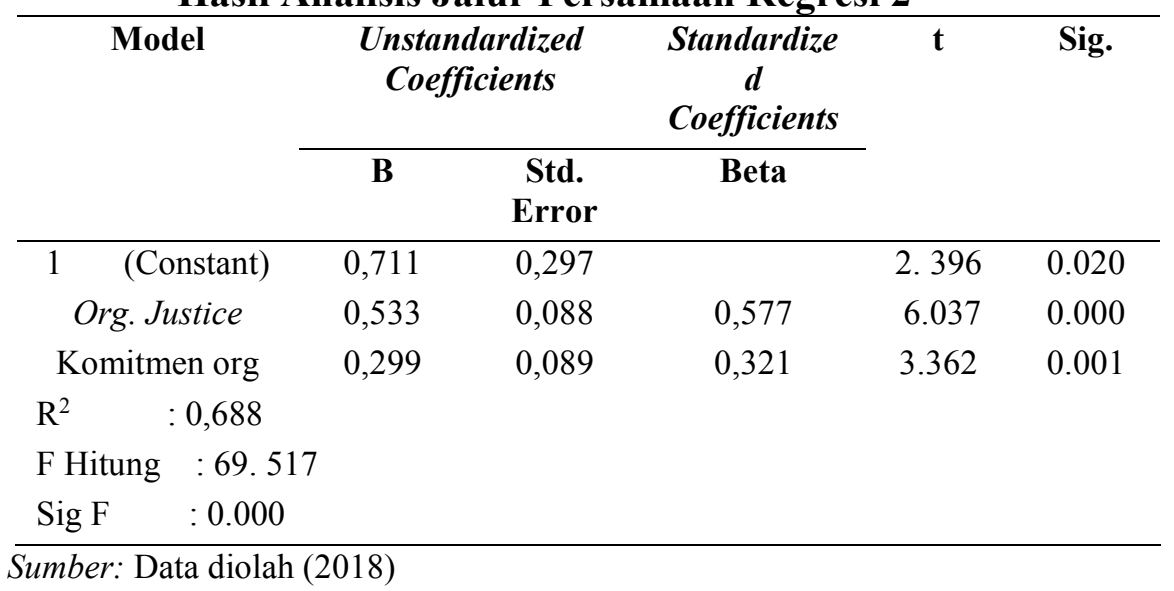


Hasil analisis jalur sub-struktur 2 seperti pada Tabel 14, maka persamaan strukturalnya adalah sebagai berikut:

$$
\begin{aligned}
& \mathrm{Y}_{2}=\beta_{2} \mathrm{X}+\beta_{3} \mathrm{X}+\mathrm{e}_{2} \ldots \ldots \ldots \ldots \ldots \ldots \ldots \ldots \\
& \mathrm{Y}_{2}=0,577 \mathrm{X}+0,321 \mathrm{X}+\mathrm{e}_{2}
\end{aligned}
$$

Berdasar hasil perhitungan pengaruh error (e), didapatkan hasil pengaruh error $\left(\mathrm{e}_{1}\right)$ sebesar 0,735 dan pengaruh error $\left(\mathrm{e}_{2}\right)$ sebesar 0,558 . Hasil koefisien determinasi total sebesar 0,814 memiliki arti bahwa sebesar 81,4 persen variasi organizational citizenship behavior dipengaruhi oleh variasi organizational justice dan komitmen organisasi, sedangkan sisanya sebesar 18,6 persen dijelaskan oleh faktor lain yang tidak dimasukkan ke dalam model.

\begin{tabular}{|c|c|c|c|}
\hline \multicolumn{4}{|c|}{$\begin{array}{c}\text { Pengaruh Langsung dan Pengaruh Tidak Langsung serta Pengaruh Total } \\
\text { Organizational Justice (X), Komitmen Organisasi (Y), Organizational } \\
\text { Citizenship Behavior (Y). }\end{array}$} \\
\hline $\begin{array}{c}\text { Pengaruh } \\
\text { Variabel }\end{array}$ & $\begin{array}{l}\text { Pengaruh } \\
\text { Langsung }\end{array}$ & $\begin{array}{c}\text { Pengaruh Tidak Langsung } \\
\text { Melalui Komitmen } \\
\text { organisasi }(M)=(\beta 1 \times \beta 3)\end{array}$ & $\begin{array}{l}\text { Pengaruh } \\
\text { Total }\end{array}$ \\
\hline $\mathrm{X} \rightarrow \mathrm{M}$ & 0,677 & & 0,677 \\
\hline$X \rightarrow Y$ & 0,577 & 0,217 & 0,794 \\
\hline $\mathrm{M} \rightarrow \mathrm{Y}$ & 0,321 & & 0,321 \\
\hline
\end{tabular}

Tabel 15.

Sumber: Data diolah (2018)

Tabel 15. menunjukkan organizational justice memiliki pengaruh langsung terhadap komitmen organisasi sebesar 0,677. Organizational justice memiliki pengaruh langsung terhadap organizational citizenship behavior sebesar 0,577 dan memiliki pengaruh tidak langsung melalui komitmen organisasi sebesar 0,217 sehingga pengaruh totalnya sebesar 0,794. Komitmen organisasi memiliki pengaruh langsung terhadap organizational citizenship behavior sebesar 0,321.

Uji sobel merupakan alat analisis untuk menguji signifikansi dari hubungan tidak langsung antara variabel independen dengan variabel dependen yang dimediasi oleh variabel mediator.

$$
\mathrm{Z}=\frac{\alpha b}{\sqrt{b^{2} S a^{2}+a^{2} S b^{2}+S a^{2} S b^{2}}}
$$

Keterangan :

$\mathrm{a}=0,677, \mathrm{~b}=0,321, \mathrm{~S}_{\mathrm{a}}=0,091, \mathrm{~S}_{\mathrm{b}}=0,089$

$$
\mathrm{Z}=\frac{0,677.0,321}{\sqrt{(0,321)^{2}(0,091)^{2}+(0,677)^{2}(0,089)^{2}+(0,091)^{2}(0,089)^{2}}}
$$




$$
\begin{aligned}
& Z=\frac{0,2137}{\sqrt{0,0009+0,0036+0,0001}} \\
& Z=\frac{0,2137}{\sqrt{0,0045}} \\
& Z=\frac{0,2137}{0,067449} \\
& Z=\mathbf{3 , 2 2 2 0}
\end{aligned}
$$

Tabel 16.

Hasil Uji Sobel

\begin{tabular}{cc}
\hline Nilai $\mathbf{T}$ & Sig \\
\hline 3,2220 & 0.000 \\
\hline
\end{tabular}

Sumber: Data diolah, (2018)

Hasil Uji Sobel pada Tabel 16. menunjukkan hasil tabulasi $Z=3,2220>1,96$ dengan tingkat signifikansi $0,000<0,05$ berarti variabel mediasi yaitu komitmen organisasi terbukti dapat memediasi pengaruh organizational justice terhadap organizational citizenship behavior sopir taksi Blue BirdGroup Jimbaran.

Berdasarkan pengujian hipotesis pada pengaruh organizational justice terhadap organizational citizenship behavior ditemukan pengaruh positif dan signifikan dengan hasil Sig. t $0,000 \leq 0,05$ serta koefisien beta sebesar 0,577 yang menunjukkan bahwa organizational justice berpengaruh positif dan signifikan terhadap organizational citizenship behavior. Hasil ini memiliki arti bahwa semakin tinggi organizational justice dalam perusahaan Blue Bird Group Jimbaran maka semakin tinggi pula organizational citizenship behavior para sopir taksi.

Hasil penelitian ini sesuai pula dengan penelitian terdahulu yang dilakukan oleh Sanhaji, Soetjipto, \& Suharto (2016)menunjukkan terdapat hubungan positif organizational justice (keadilan organisasi) dengan OCB, bahwa OCB berhubungan positif terhadap keadilan distributif, prosedural dan interaksional. Penelitian yang dilakukan oleh Polat (2016)juga memperoleh kesimpulan bahwa dimensi keadilan distributif, keadilan prosedural, dan keadilan interaksional memiliki pengaruh positif signifkan terhadap OCB. Penelitian Ibrahim \& Perez (2014)menunjukkan bahwa keadilan organisasional berpengaruh postitif terhadap organizational citizenship behavior. Penelitian ini juga serupa dengan penelitian yang dilakukan oleh Nwibere (2014)yang menunjukkan bahwa tanggapan karyawan mengenai keadilan organisasi memiliki pengaruh positif dan signifikan terhadap OCB. Karyawan yang merasa telah diperlakukan dengan adil oleh organisasi, maka perilaku extra-role dari karyawan meningkat.

Berdasarkan pengujian hipotesis pengaruh organizational justice terhadap komitmen organisasi ditemukan pengaruh positif dan signifikan dengan hasil Sig. t $0,000 \leq 0,05$ serta koefisien beta sebesar 0,677 yang menunjukkan bahwa organizational justice berpengaruh positif dan signifikan terhadap komitmen organisasi. Hasil ini memiliki arti bahwa semakin tinggi organizational justice dalam perusahaan Blue Bird Group Jimbaran maka semakin tinggi pula komitmen organisasi para sopir taksi terhadap Blue Bird Group Jimbaran. 
Hasil penelitian ini serupa dengan penelitian terdahulu oleh Mensah, Asiamah, \& Mireku (2016) mengatakan bahwa keadilan organisasional berpengaruh positif terhadap komitmen organisasional. Penelitian Lashari et al. (2016) di University of Sargodha menemukan keadilan organisasi memiliki pengaruh positif dan signifikan terhadap komitmen organisasi pegawai. Penelitian yang juga dilakukan oleh Sancoko \& Panggabean (2015)memperoleh hasil bahwa keadilan organisasional berpengaruh positif dan signifikan terhadap komitmen organisasional.

Berdasarkan hipotesis pada pengaruh komitmen organisasi terhadap organizational citizenship behavior ditemukan pengaruh positif dan signifikan dengan hasil Sig. t 0,001 serta koefisien beta sebesar 0,321 yang menunjukkan bahwa komitmen organisasi berpengaruh positif dan signifikan terhadap organizational citizenship behavior. Hasil ini memiliki arti bahwa semakin tinggi komitmen organisasi para sopir taksi terhadap Blue Bird Group Jimbaran maka semakin tinggi pula organizational citizenship behavior para sopir taksi. Hasil penelitian ini sesuai pula dengan penelitian terdahulu yang dilakukan oleh Ortiz, Rosario, Marquez, \& Gruneiro (2015)menunjukan bahwa terdapat hubungan yang positif antara komitmen organisasi dengan OCB. Penelitian Barusman \& Mihdar (2014) yang menyatakan komitmen organisasional berpengaruh positif terhadap OCB. Penelitian menurut Kencanawati (2014)komitmen organisasi berpengaruh signifikan terhadap OCB.

Pengujian hipotesis dalam penelitian ini menggunakan Uji Sobel dan memperoleh hasil Z sebesar 3,2220 (>1,96) dengan tingkat nilai signifikansi 0,000 $(<0,05)$ yang menandakan bahwa komitmen organisasi secara positif dan signifikan memediasi pengaruh antara organizational justice terhadap organizational citizenship behavior. Hasil ini memiliki arti bahwa semakin tinggi organizational justice Blue Bird Group Jimbaran, maka semakin tinggi pula komitmen organisasi para sopir taksi dan dengan demikian organizational citizenship behavior para sopir taksi akan meningkat.

Hasil penelitian ini sesuai pula dengan penelitian terdahulu yang dilakukan oleh Suwandewi \& Sintaasih (2016)menemukan bahwa keadilan organisasional memiliki pengaruh positif dan signifikan terhadap komitmen organisasional. Penelitian Bara et al.(2016)menemukan bahwa komitmen organisasi berpengaruh positif dan signifikan terhadap OCB. Penelitan Khan \& Rashid (2012)memperolehhasil bahwa komitmen organisasi merupakan variabel mediasi yang sesuai untuk mengetahui hubungan antara budaya organisasi, gaya kepemimpinan, dan keadilan organisasi terhadap OCB, karena pada penelitian ini komitmen organisasi berpengaruh positif dan signifikan terbesar bila dibandingkan dengan variabel yang lainnya.

\section{SIMPULAN}

Simpulan dalam penelitian ini di ambil, bersumber pada hasil analisis adalah sebagai berikut. (1) Organizational justice memiliki pengaruh positif dan signifikan terhadap organizational citizenship behavior sopir taksi Blue Bird Group Jimbaran. Hal ini menunjukkan semakin tinggi tingkat organizational justice dalam perusahaan maka semakin kuat pula tingkat organizational 
citizenship behavior yang dimiliki oleh para sopir taksi Blue Bird Group Jimbaran. (2) Organizational justice berpengaruh positif dan signifikan terhadap komitmen organisasi sopir taksi Blue BirdGroup Jimbaran. Hal ini menunjukkan semakin tinggi tingkat organizational justice dalam perusahaan maka semakin kuat pula tingkat komitmen organisasi yang dimiliki oleh para sopir taksi terhadap Blue Bird Group Jimbaran. (3) Komitmen organisasi memiliki pengaruh positif dan signifikan terhadap organizational citizenship behavior sopir taksi Blue BirdGroup Jimbaran. Hal ini menunjukkan semakin tinggi tingkat komitmen organisasi para sopir taksi maka semakin kuat pula tingkat organizational citizenship behavior yang dimiliki oleh para sopir taksi Blue Bird Group Jimbaran. (4) Komitmen organisasi mampu memediasi pengaruh organizational justice terhadap organizational citizenship behavior. Hal ini menunjukkan bahwa pengaruh variabel organizational justice terhadap variabel organizational citizenship behavior mengalami peningkatan dengan adanya variabel komitmen organisasi. Apabila organizational justice semakin tinggi, maka itu akan berdampak pada komitmen organisasi yang nantinya akan mampu menciptakan organizational citizenship behavior pada sopir taksi Blue Bird Group Jimbaran.

Saran yang dapat diberikan berdasarkan hasil analisis, pembahasan dan simpulan di atas, adalah sebagai berikut: (1) Pihak Blue Bird Group Jimbaran hendaknya memperhatikan organizational citizenship behavior dalam diri masing-masing individu. Jika di lihat dari rata-rata indikator pada variabel organizational citizenship behavior, nilai rata-rata terendah terdapat pada pernyataan "saya selalu memanfaatkan waktu dengan efisien", hal tersebut berarti para sopir taksi belum dapat memanfaatkan waktu dengan efisien. Maka, pimpinan hendaknya meningkatkan pengawasan terhadap peraturan dan waktu tugas para sopir taksi. (2) Pihak Blue Bird Group Jimbaran hendaknya memperhatikan komitmen organisasi para sopir taksi. Jika di lihat dari rata-rata indikator pada variabel komitmen organisasi, nilai rata-rata terendah terdapat pada pernyataan "saya merasa bangga dapat menjadi bagian dari perusahaan", hal tersebut berarti para sopir taksi belum merasa bangga dapat menjadi bagian dari perusahaan. Hal ini disebabkan oleh munculnya taksi online sehingga memberi dampak pada para sopir taksi konvensional. Maka, perusahaan hendaknya memperhatikan kondisi psikis para sopir taksi agar tidak merasa tersaingi dengan para sopir taksi online lainnya, sehingga dapat meningkatkan komitmen organisasi para sopir taksi terhadap perusahaan. (3) Pihak Blue Bird Group Jimbaran hendaknya memperhatikan pula organizational justice dalam perusahaan, jika di lihat dari rata-rata indikator pada variabel organizational justice, nilai rata-rata terendah terdapat pada pernyataan "saya diberikan kesempatan untuk berpendapat oleh perusahaan", hal tersebut berarti para sopir taksi belum mendapatkan kesempatan untuk berpendapat oleh perusahaan. Maka, perusahaan hendaknya menyetarakan status para sopir taksi dengan karyawan lainnya sehingga keadilan organisasi dapat dirasakan pula oleh para sopir taksi.

\section{REFERENSI}


Adeyemo, D. (2007). Emotional Intelligence and the Relationship between Job Satisfaction and Organizational Commitment of Employee in Public Parastatals in Oyo State Nigeria. Pakistan Journal of Social Sciences, 4(2), 324-330.

Adiapsari, R. (2012). Analisis Pengaruh Iklim Organisasi terhadap Komitmen dengan Kepuasan Kerja sebagai Variabel Mediasi pada Karyawan PT Tiga Serangkai Solo. Riset Manajemen Dan Akuntansi, 3(5), 75-102.

Allameh, S. M., Shahriari, M., \& Mansoori, H. (2012). Investigating Employee's Attitude Toward Organization, Organizational Climate and Employee's Engagement As Antecedents of Organizational Citizenship Behavior. Australian Journal of Basic and Applied Sciences, 6(8), 384-393.

Andriani, G. (2012). Organizational Citizenship Behavior dan Kepuasan Kerja pada Karyawan. Jurnal Penelitian Psikologi, 3(1), 341-345.

Aryee, S., Budhwar, P. S., \& Chen, Z. X. (2002). Trust as a Mediator of the Relationship between Organizational Justice and Work Outcomes: Test of a Social Exchange Model. Journal of Organizational Behavior, 1(23), 267285.

Awang, R., \& Wan, M. R. (2015). The Impact of Organizational Justice on Organizational Citizenship Behavior in Malaysian Higher Education. Mediterranean Journal of Social Sciences, 6(5), 674-678.

Bara, D. D., Patricia, D. P., \& Andi, T. . (2016). Pengaruh Komitmen Organisasi, Kepuasan Kerja, dan Budaya Organisasi terhadap Organizational Citizenship Behavior (OCB) yang berdampak pada Prestasi Kerja Karyawan (Studi pada PT. PLN APP Semarang ). Journal Of Management, 2(2), 1-10.

Barusman, \& Mihdar. (2014). The Effect of Job Satisfaction and Organizational Justice on Organizational Citizenship Behavior with Organization Commitment as the Moderator. International Journal of Humanities and Social Science, 4(9), 118-126.

Colquitt, J. A. (2001). On the Dimensionality of Organizational Justice: A construct validation of a measure. Journal of Applied Psychology, 86(3), 386-400.

Cropanzano, R., \& Mitchell, M. S. (2005). Social Exchange Theory: An Interdidisciplinary Review. Journal Of Management, 31(6), 874-900.

Darmawati, A., Hidayati, L. N., \& Herlina, D. (2013). Pengaruh Kepuasan Kerja dan Komitmen Organisasi terhadap Organizational Citizenship Behavior. Jurnal Economia, 9(1), 1-10.

Dehkordi, M., \& Yektayar. (2013). Relationship of Organizational Justice and Organizational Commitment of the Staff in General Directorate of Youth and 
Sports in Chahar Mahal Va Bakhtiari Province. Pelagia Research Library, 3(3), 696-700.

Fitria, R. M., Dewi, R. S., \& Febriana, S. K. T. (2015). Peranan Komitmen Organisasi Terhadap Organizational Citizenship Behavior Pada Perawat. Jurnal Ecopsy, 2(1), 8-12.

Fung, N. S., Ahmad, A., \& Zoharah, O. (2015). Work-Family Enrichment: Its Mediating Role in the Relationships Between Workplace Support Factors and Teachers Job Satisfaction. American Journal of Applied Sciences, 12(4), 242-253.

Ibrahim, M. E., \& Perez, A. O. (2014). Effects of Organizational Justice, Employee Satisfaction, and Gender on Employees Commitment: Evidence from the UAE. International Journal of Business and Management, 9(2), 4559.

Indrayani, L. P. C., \& Suwandana, I. G. M. (2016). Pengaruh Keadilan Organisasional Terhadap Kepuasan Kerja dan Komitmen Organisasional Pada Karyawan. E-Jurnal Manajemen Unud, 5(6), 3589-3619.

Karim, \& Reham. (2012). Impact of Job Satisfaction, Perceived Organizational Justice and Employee Empowerment on Organizational Commitment in Semi Government Organizations of Pakistan. Journal of Business Studies Quarterly, 3(4), 92-104.

Kencanawati, A. A. . (2014). Gaya Kepemimpinan, Komitmen Organisasi dan Kepuasan Kerja Mempengaruhi Organizational Citizenship Behavior pada PT. (BPR) Cahaya Bina Putra Kerobokan Badung. Jurnal Manajemen Dan Kewirausahaan, 10(1), 44-45.

Khan, M., \& Rashid. (2012). The Impact of Organizational Commitment on Employee Job Performance. European Journal of Sciences, 15(3), 292-298.

Konovsky, M. ., \& Pugh, S. D. (1994). Citizenship Behavior and Social Exchange. Academy of Management Journal, 37(3), 54-58.

Kristanto, H. (2015). Keadilan Organisasional, Komitmen Organisasional, dan Kinerja Karyawan. Journal Manajemen Dan Kewirausahaan, 17(1), 86-98.

Kurniawan, A. (2015). Pengaruh Komitmen Organisasi Terhadap Organizational Citizenship Behavior (OCB) PT X Bandung. Jurnal Manajemen, 15(1), 95118.

Lashari, M., Moazzam, A., Salman, Y., \& Irfan, S. (2016). Impact of Organizational Trust on Organizational Justice and Organizational Commitment: A Case of University of Sargodha. Journal If the Research Society of Pakistan, 53(2), 170-194. 
Marissa. (2010). Pengaruh Persepsi tentang Keadilan Organisasi terhadap Komitmen Organisasi Karyawan PT. Garuda Indonesia (Persero). Universitas Islam Negeri Syarif Hidayatullah.

Mensah, H. K., Asiamah, N., \& Mireku, K. (2016). The Effect of Organizational Justice Delivery on Organizational Commitment Controlling for Key Confounding Variables. Journal of Global Responsibility, 7(2), 196-209.

Meyer, J. ., \& Herscovitch, L. (2001). Commitment in the Workplace: Toward a General Model. Human Resource Management Review, 11(1), 299-326.

Meyer, J., Becker, T., \& Van, R. (2006). Social Identities and Commitments at Work: Toward an Integrative Model. Journal of Organizational Behaviour, $27(1), 665-683$.

Moorman, R. H., Niehoff, B., \& Organ, D. W. (1993). Treating Employees Fairly and Organizational Citizenship Behaviors: Sorting the Effects of Job Satisfaction, Organizational Commitment and Procedural Justice. Employee Responsibilities and Rights Journal, 6(3), 209-225.

Muchinsky, P. . (2008). Psychology Applied to Work: An Introduction to Industrial and Organizational Psychology. Summerfield: Hypergraphic Press.

Najafi, S., Noruzy, A., Azar, H. K., Nazari-Shirkouhi, S., \& Dalvand, M. R. (2011). Investigating The Relationship Between Organizational Justice, Psychological Empowerment, Job Satisfaction, Organizational Commitment and Organizational Citizenship Behavior: An Empirical Model. African Journal of Business Management, 5(13), 5241-5248.

Nandan, T., \& Abdul, M. M. A. (2015). Organizational Justice and Organizational Citizenship Behavior: Mediating Role of Psychological Capital. American International Journal of Social Science, 4(6), 148-156.

Noordin, F., Omar, S., Sehan, S., \& Idrus, S. (2010). Organizational Climate and Its Influence on Organizational Commitment. International Business \& Economic Research Journal, 9(2), 1-10.

Nwibere, B. M. (2014). Organizational Justice As a Determinant of Organizational Citizenship Behavior in the Nigerian in the Niger Delta Region. International Journal of Business and Management, 9(4), 191-205.

Oceani, \& Sriathi. (2015). Pengaruh Gaya Kepemimpinan Transformasional dan Keadilan Organisasi terhadap Komitmen Organisasi Karyawan dibagian Housekeeping pada Hotel Bali Dynasty Resort Kuta. E-Jurnal Manajemen Unud, 4(10), $2912-2927$.

Organ, D. W., Podsakoff, P. M., \& MacKenzie, S. B. (2006). Organizational Citizenship Behavior: Its Nature, Antecedents, and Consequences. Thousand 
Oaks, California: Sage Publications.

Ortiz, M. Z., Rosario, E., Marquez, E., \& Gruneiro, P. C. (2015). Relationship between Organizational Commitments and Organizational Citizenship Behaviour in a sample of Private Banking Employees. International Journal of Sociology and Social Policy, 35(1), 91-106.

Ozkalp, E., \& Kirel, C. (2004). Orgutsel davranıs. Eskisehir: Anadolu University Press.

Polat, S. (2016). The Relationship Between Organizational Justice Perceptions, Level of School and Administrator Trust, and Organizational Citizenship Behaviors of Secondary School Teacher Turkey. International Business \& Economics Research Journal, 1(1), 1-10.

Praditya, I. M. D. I., \& Putra, M. S. (2016). Pengaruh Keadilan Organisasional Terhadap Kepuasan Kerja Dan Komitmen Organisasional Karyawan Di Wina Holiday Villa. E-Jurnal Manajemen Unud, 5(6), 3532-3559.

Prameswari, N. K. S. (2017). Pengaruh Keadilan Organisasional, Komitmen Organisasional, dan Kepuasan Kerja terhadap Organizational Citizenship Behavior. E-Jurnal Manajemen Unud, 6(3), 1368-1397.

Rini, D. P., Rusdarti, \& Suparjo. (2013). Pengaruh Komitmen Organisasi, Kepuasan Kerja dan Budaya Organisasi terhadap Organizatinal Citizenship Behaviour (OCB) (Studi pada PT. Plasa Simpanglima Semarang). Jurnal Ilmiah Dinamika Ekonomi Dan Bisnis, 1(1), 2337-6082.

Robbins, S. (2006). Perilaku Organisasi: Konsep, Kontraversi dan Aplikasi Edisi Kedua Terjemahan Pudjaatmaka. Jakarta: Prenhallind.

Robbins, S. P., \& Judge, T. A. (2015). Perilaku Organisasi. Jakarta: Salemba Empat.

Sancoko, C. A., \& Panggabean, M. S. (2015). Pengaruh Keadilan Organisasi terhadap Komitmen Organisasi dengan Kepuasan Kerja Sebagai Variabel Intervening di Sekolah Santa Ursula BSD. Jurnal MIX, 5(1), 34-53.

Sanhaji, A., Soetjipto, E. B., \& Suharto. (2016). Pengaruh Keadilan Organisasi dan Budaya Organisasi terhadap Perilaku Kewarganegaraan Organisasi melalui Komitmen Organisasi dan Kepuasan Kerja. Jurnal Pendidikan Teori, Penelitian, Dan Pengembangan, 1(5), 917-926.

Soegandhi., V. M., Setiawan, E. M. S., \& Roy. (2013). Pengaruh Kepuasan Kerja dan Loyalitas Kerja terhadap Organizational Citizenship Behavior pada karyawan PT. Surya Timur Sakti Jatim. AGORA, 1(1), 1-10.

Sugiyono. (2017). Metode Penelitian Bisnis. Bandung: Alfabeta.

Sutrisna, I. W. W., \& Rahyuda, A. G. (2014). Pengaruh Keadilan Distributif, 
Prosedural, dan Interaksional terhadap Kepuasan Kerja dan Komitmen Organisasi pada Paramedis di Rumah Sakit Tk II Udayana Denpasar. EJurnal Manajemen Udayana, 3(9), 2489 - 2509.

Suwandewi, N. N. T., \& Sintaasih, D. K. (2016). Keadilan Organisasional dan Komitmen Organisasional: Efeknya pada Organizational Citizenship Behavior. E-Jurnal Manajemen Unud, 5(7), 4453-4485.

Tahseen, N., \& Akhtar, M. S. (2016). Impact of Organizational Justice on Citizenship Behavior: Mediating Role of Faculty Trust. Pakistan Journal of Commerce and Social Sciences, 10(1), 104-121.

Waspodo, A. A. W. S., \& Minadaniati, L. (2012). Pengaruh Kepuasan Kerja dan Iklim Organisasi terhadap Organizational Citizenship Behavior (OCB) Karyawan pada PT. Trubus Swadaya. Jurnal Riset Manajemen Sains Indonesia (JRMSI), 3(1), 1-16.

Wibowo. (2012). Manajemen Kinerja. Jakarta: Raja Grafindo Persada. 